\title{
Сладкова Н.А., Перепелкин В.В. \\ Комплексное исследование биоценоза побережья о. Ристисаари и оценка качества пресных вод северной части Ладожского озера
}

Санкт-Петербургский государственный университет ветеринарной медицины (Россия, Санкт-Петербург)

doi: 10.18411/trnio-09-2021-04

\section{Аннотация}

Произведено комплексное исследование пресноводного биоценоза побережья острова Ристисаари северной части Ладожского озера. Составлена карта растительных ассоциаций, определен видовой состав макрофитов, составляющих фитоценоз побережья острова. Произведен качественный и количественный анализ зообентоса, осуществлена оценка качества вод по индексу Майера и олигохетному индексу Гуднайт - Уотлея.

Ключевые слова: пресноводный биоценоз, зообентос, биоиндикация, индекс Майера, индекс Гуднайт - Уотлея.

\section{Abstract}

A comprehensive study of the freshwater biocenosis of the coast of Ristisaari Island in the northern part of Lake Ladoga was carried out. A map of plant associations was compiled, the species composition of macrophytes that make up the phytocenosis of the island's coast was determined. Qualitative and quantitative analysis of zoobenthos was carried out, water quality was assessed according to Mayer index and index Goodnight - Watley.

Keywords: freshwater biocenosis, zoobenthos, bioindication, Mayer index, Goodnight Watley index.

Озера - это компоненты гидросферы, издавна играющие огромную роль в жизни человека. В настоящее время, когда антропогенная нагрузка на биогеоценозы велика, всестороннее изучение озерных экосистем не только способствует более глубокому пониманию сложных взаимодействий, составляющих эти уникальные природные комплексы, но и позволяет разработать рекомендации, способствующие сохранению этих естественных резервуаров пресной воды на нашей планете от вредного воздействия со стороны человека.

Цель работы - описать компоненты биоценоза побережья острова Ристисаари Ладожского озера и произвести оценку качества вод с помощью биоиндикационных методов.

Район исследования - остров Ристисаари - расположен в Ладожском озере, относится к северным Ладожским шхерам. Остров расположен к западу от полуострова Хуунукка, от которого отделён узким проливом. Административно относится к Питкярантскому району Карелии.

Климат острова умеренный, переходный от умеренно континентального к умеренноморскому. Такой тип климата объясняется географическим положением и атмосферной циркуляцией. Это обуславливается сравнительно небольшим количеством поступающего на земную поверхность и в атмосферу солнечного тепла.

Ландшафт района исследования среднетаежный скальный слабозаболоченный с ярко выраженным преобладанием сосновых местообитаний. Территория характеризуется узкими глубоко вдающимися в сушу заливами Ладожского озера, сильно пересеченной местностью, сравнительно высокими скальными грядами. [1]

Исследуемый участок был зафиксирован с помощью аэросъемки - им является небольшая бухта в южной части острова.

Описание фитоценоза. Для описания биоценоза был произведен ручной сбор и фотографирование образцов макрофитов и последующее нанесение растительных 
ассоциаций на карту бухты. Полный видовой список высших водных растений, составляющий фитоценоз исследуемого района представлен в таблице 1. [5]

Таблища 1

Видовой состав фитоценоза бухтыл

\begin{tabular}{|c|c|c|c|c|}
\hline Семейство & Pod & Вид (лат.) & Вио (pyc.) & Euomon \\
\hline Lamiaceae & Scutellaria & S. galericulata $(L)$. & $\begin{array}{c}\text { Шлемник } \\
\text { обыкновенный }\end{array}$ & $\begin{array}{c}\text { мелководная } \\
\text { каменистая литораль }\end{array}$ \\
\hline Ranunculaceae & Caltha & C. palustris (L.) & Калужница болотная & $\begin{array}{c}\text { мелководная } \\
\text { каменистая литораль }\end{array}$ \\
\hline Haloragaceae & Myriophyllum L. & M. spicatum (L.) & Уруть колосистая & $\begin{array}{c}\text { мелководная } \\
\text { крупнокаменистая } \\
\text { литораль }\end{array}$ \\
\hline $\begin{array}{c}\text { Potamogetonacea } \\
e \\
\end{array}$ & Potamogeton L. & P. gramineus (L.) & Рдест разнолистный & $\begin{array}{c}\text { крупнокаменистая } \\
\text { литораль }\end{array}$ \\
\hline Cyperaceae & $\begin{array}{c}\text { Eleocharis } R . \\
B r .\end{array}$ & E. patustris (L.) & Ситняг болотный & $\begin{array}{c}\text { мелководная } \\
\text { каменистая литораль }\end{array}$ \\
\hline $\begin{array}{c}\text { Potamogetonacea } \\
e\end{array}$ & Potamogeton L. & P. perfoliatus (L.) & $\begin{array}{c}\text { Рдест } \\
\text { пронзённолистный }\end{array}$ & $\begin{array}{c}\text { мелководная } \\
\text { каменистая литораль }\end{array}$ \\
\hline Umbelliferae & Cicuta & C. virosa (L.) & Вех ядовитый & $\begin{array}{c}\text { мелководная } \\
\text { каменистая литораль }\end{array}$ \\
\hline Polygonaceae & Persicaria Mill. & $\begin{array}{c}\text { P. amphibia (L.) S.F. } \\
\text { Gray }\end{array}$ & Горец земноводный & $\begin{array}{c}\text { мелководная } \\
\text { каменистая литораль }\end{array}$ \\
\hline Equisetaceae & Equisétum & E. fluviatile (L.) & Хвоч речной & $\begin{array}{c}\text { мелководная } \\
\text { каменистая литораль }\end{array}$ \\
\hline Cyperaceae & Carex & C. $\operatorname{acuta}(L)$. & Осока острая & $\begin{array}{c}\text { мелководная } \\
\text { каменистая литораль }\end{array}$ \\
\hline Alismatáceae & Sagittaria & S. sagittifolia (L.) & $\begin{array}{c}\text { Стррелолист } \\
\text { обыкновенный }\end{array}$ & $\begin{array}{c}\text { мелководная } \\
\text { каменистая литораль }\end{array}$ \\
\hline Ranunculaceae & Ranunculus & R. inundatus & Лютик водный & $\begin{array}{c}\text { мелководная } \\
\text { каменистая литораль }\end{array}$ \\
\hline Primulaceae & Lysimachia & $\begin{array}{l}\text { L. thyrsiflora (L.) } \\
\text { Sp. Pl. }\end{array}$ & Кизляк кистецветный & $\begin{array}{c}\text { мелководная } \\
\text { каменистая литораль }\end{array}$ \\
\hline
\end{tabular}

На основании полученных данных составлена схема пространственного распределения различных растительных ассоциаций по площади биотопа (рис.1). Точками на рисунке обозначены станции отбора проб макрозообентоса №1-№12.
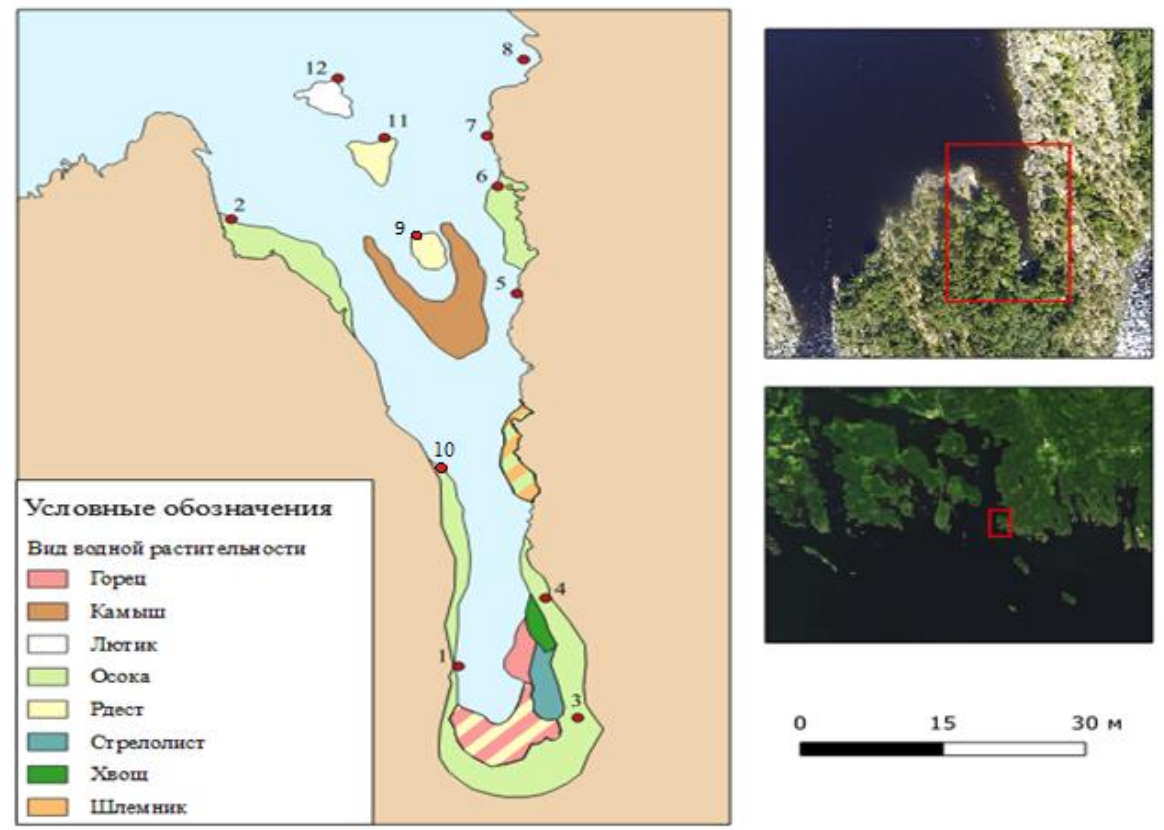

Рисунок 1. Схема бухты, отражающая пространственное распределение растительных ассоџиаџий 
Описание видового состава зообентоса. По всей площади бухты были установлены станции (ст. 1, ст. 10, ст. 11.), с которых совершался отбор проб для качественного и количественного анализа макро- и мезобентоса.

Отбор проб совершался с помощью дночерпателя Экмана - Берджа и производился ручной сбор животных на каменистой литорали. [2] Видовой список макрозообенотоса представлен в таблице 2. [3]

Таблииа 2

Макрозообентос бухты

\begin{tabular}{|c|c|c|c|c|}
\hline Класс & Отряд & Семейство & Pod & Вид \\
\hline $\begin{array}{c}\text { Gastropoda } \\
\text { Брюхоногие } \\
\text { моллюски }\end{array}$ & Hygrophyla & Limnaeidae & $\begin{array}{c}\text { Lymnaea (Lamarck, } \\
\text { 1799) }\end{array}$ & - \\
\hline \multirow{2}{*}{$\begin{array}{c}\text { Crustacea } \\
\text { Ракообразньые }\end{array}$} & \multirow{2}{*}{ Amphipoda } & Micruropodidae & $\begin{array}{c}\text { Gmelinoides } \\
\text { (Bazikalova, 1945) }\end{array}$ & $\begin{array}{c}\text { Gmelinoides } \\
\text { fasciatus (Stebbing, } \\
1899)\end{array}$ \\
\hline & & Gammaridae & $\begin{array}{c}\text { Gammarus } \\
\text { (Fabricius, 1775) }\end{array}$ & $\begin{array}{c}\text { Gammarus lacustris } \\
\text { (G. O. Sars, 1863) }\end{array}$ \\
\hline \multirow{6}{*}{$\begin{array}{c}\text { Insecta } \\
\text { Насекомые }\end{array}$} & \multirow{2}{*}{$\begin{array}{l}\text { Trichoptera } \\
\text { Ручейники }\end{array}$} & $\begin{array}{c}\text { Lерtoceridae, тип } \\
\text { домика-песок }\end{array}$ & 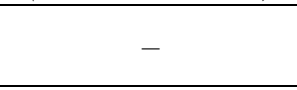 & 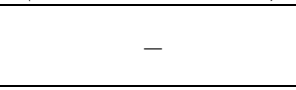 \\
\hline & & $\begin{array}{c}\text { Rhyacophilidae, mun } \\
\text { домика - дресва }\end{array}$ & - & - \\
\hline & $\begin{array}{l}\text { Plecoptera } \\
\text { Веснянки }\end{array}$ & 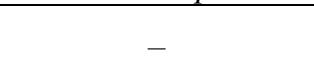 & - & - \\
\hline & $\begin{array}{c}\text { Ephemeroptera } \\
\text { Падёнки }\end{array}$ & Heptageniidae & - & - \\
\hline & Odonata & - & - & - \\
\hline & Hemiptera & Notonectidae & Notonecta & Notonecta glauca \\
\hline Gordioida & Chordodea & Gordiidae & Gordius & Gordius aquaticus \\
\hline Clitellata & Rhynchobdellida & Glossiphoniidae & Glossiphonia & $\begin{array}{c}\text { Glossiphonia } \\
\text { complanata } \\
\end{array}$ \\
\hline Malacostraca & Isopoda & Asellidae & Asellus & Asellus aquaticus \\
\hline Turbellaria & Tricladida & - & - & - \\
\hline
\end{tabular}

Оценка состояния вод с помощью биоиндикационных методов. Для оценки состояния водоемов использовались пробы бентоса, собранные с помощью дночерпателя на станциях 1, 10, 11, а также учитывались результаты, приведенные в таблице 2.

Метод, основанный на индексе Майера, использует приуроченность различных групп водных беспозвоночных к водоёмам с определённым уровнем загрязнённости. В данном методе организмы-индикаторы отнесены к одному из трёх разделов в соответствии с таблицей 3. [4]

Таблиия 3

Индекс Майера

\begin{tabular}{|c|c|c|}
\hline Обитатели чистых вод & $\begin{array}{c}\text { Организмы средней степени } \\
\text { чувствительности }\end{array}$ & $\begin{array}{c}\text { Обитатели загрязненных } \\
\text { водоёмов }\end{array}$ \\
\hline Нимфы веснянок & Бокоплав & Личинки комаров-звонцчов \\
\hline Нимфы поденок & Речной рак & Пиявки \\
\hline Личинки ручейников & Личинки стрекоз & Водяной ослик \\
\hline Личинки вислокрылок & Личинки комаров-долгоножек & Прудовики \\
\hline Двустворчатье моллюски & Моллюски-катушки & Личинки мошки \\
\hline- & Моллюски-живородки & Малощетинковые черви \\
\hline
\end{tabular}

Количество обнаруженных групп из первого раздела таблицы умножалось на три, количество групп из второго раздела - на два, а из третьего - на один. Получившиеся цифры суммировали. Значение суммы характеризует степень загрязнённости водоёма. [4] 
Исходя из данных сбора животных, отраженных в таблице 2, индекс Майера $=20$. Таким образом, исследуемый водоем является олигосапробным.

Оценка состояния водоема с помощью олигохетного индекса Гуднайт-Уотлея. Данная методика используется для определения загрязнения водоема органическими веществами. Учитываются только результаты дночерпательных проб. [4] На основе полученных данных по пробам с трех станций (№1, №10 и №11) олигохетный индекс составил соответственно $\mathrm{a}_{\mathrm{crl}}=15,3 \%, \mathrm{a}_{\text {ст.10. }}=3,8 \%, \mathrm{a}_{\text {ст.11. }}=5,7 \%$. Из полученных значений можно сделать вывод, что доля олигохет в каждой из проб незначительна, водоем не загрязнен органическими веществами.

Заключение. На основании данных полученных в исследовании составлена карта биотопа, исследован фитоценоз и составлен полный видовой список макрофитов бухты острова Ристисаари в шхерном районе севера Ладожского озера. На основе списка видового состава макрозообентоса определена степень загрязненности воды Ладожского озера в исследуемом районе. Водоём в изучаемой местности характеризуется как олигосапробный, загрязнения органическими веществами не были отмечены.

$$
* * *
$$

1. Громцев А. Ладожские шхеры - уникальный скалистый ландшафт Европы. Институт леса Карельского научного центра РАН. Карельский экологический журнал «Зелёный лист»; 2012 г., декабрь, № 2. С. 6.

2. Жадин В. И. Методы гидробиологического исследования. - М.: Высшая школа, 1960, 189 с.

3. Определитель пресноводных беспозвоночных Европейской части СССР: планктон и бентос / отв. ред. Л. А. Кутикова, Я. И. Старобогатов. - Ленинград: Гидрометеоиздат, 1977. - 512 с.

4. Псарев А.М. Руководство к учебной практике по экологии: биоиндикация / А.М. Псарев; Алтайский государственный гуманитарно-педагогический университет имени В.М. Шукшина - Бийск: АГГПУ им. В.М. Шукшина, $2018-65$ с.

5. Рябова В.Н., Васильева В.А. Полевой атлас-определитель растений и животных - индикаторов загрязнения пресноводных водоемов / В.Н. Рябова. - СПб.: Старый Петергоф, 2011, 48c.

Tарасова A.O.

Влияние льняного жмыха на показатели роста и развития молодняка лошадей Курганская ГСХА имени Т.С. Мальцева (Россия, Курган)

doi: 10.18411/trnio-09-2021-05

\section{Аннотация}

Работа посвящена изучению влияния различных дозировок льняного жмыха на показатели живой массы и основных промеров молодняка лошадей русской тяжеловозной породы. В результате исследований установлено, что использование льняного жмыха в рационе молодняка лошадей положительно повлияло на прирост живой массы, привело к увеличению основных промеров телосложения. Лучшие результаты по всем исследуемым показателям были у подопытных животных, в рационы которым включали льняной жмых в дозе 500 г на голову в сутки.

Ключевые слова: льняной жмых, рационы, молодняк лошадей, живая масса, промеры телосложения.

\section{Abstract}

The paper is devoted to the study of the influence of various dosages of linseed cake on the indicators of live weight and the main body measurements of young horses of the Russian Heavy Draft breed. As a result of the research, it was found that the use of linseed cake in the diet of young horses had a positive effect on the live weight gain, led to an increase in the main body measurements. The best results for all the studied indicators were in experimental animals, which diets included linseed cake at a dose of $500 \mathrm{~g}$ per head per day.

Keywords: linseed cake, diets, young horses, live weight, body measurements. 